\title{
Survival and gill morphology of different life stages of Tilapia guineensis exposed to the drilling fluid XP-07
}

\author{
Sobrevivência e morfologia branquial de Tilapia guineensis expostos ao líquido de perfuração XP-07 \\ em diferentes estágios de vida
}

\author{
Ijeoma Favour Vincent-Akpu ${ }^{\mathrm{I}^{*}}$ Martin Ebisingha Allison ${ }^{\mathrm{II}}$ Francis David Sikoki ${ }^{\mathrm{I}}$
}

\begin{abstract}
The toxicity of drilling fluid XP-07 on gills of three life stages (fry, fingerling and post fingerling) of Tilapia guineensis was evaluated in a $96 \mathrm{~h}$ static bioassay. The mortality rates of the organisms were determined using the same concentrations of XP-07 in all the life stages. At the end of $96 \mathrm{~h}$, the gills were examined for histopathological changes. The $96 \mathrm{~h}$ median lethal concentrations for fry (Fr), fingerlings ( $F$ ) and post fingerlings (PF) were 5.03, 7.77 and $6.93 \%$ XP-07 respectively. The median lethal time values decreased as concentration and time of exposure increased. The histopathological studies carried out on gills of T. guineensis showed injuries, which increased progressively with the concentration of the fluid. The fry stage was the most susceptible to the drilling fluid. This states the need for care to be taken in handling drilling fluids in Niger delta, since this area serves as breeding and nursery ground for several fish species.
\end{abstract}

Key words: toxicity, histopathology, Niger delta, drilling, fluid, median lethal concentration $\left(L C_{50}\right)$, median lethal time $\left(L T_{50}\right)$, Teleost.

\section{RESUMO}

A toxicidade do líquido de perfuração XP-07, nas brânquias de Tilapia guineensis, foi avaliada por meio de um bioensaio estático de $96 \mathrm{~h}$ em três estágios da vida do peixe (larva, alevino e juvenil). As taxas de mortalidade do organismo foram avaliadas nas mesmas concentrações de XP-07 para todos os estágios de vida do peixe. As brânquias foram avaliadas ao final de 96 horas, com o objetivo de observarem-se mudanças histopatológicas. A concentração média letal para $96 \mathrm{~h}$ foi de 5,03; 7,77 e 6,93\% para larvas, alevinos e juvenis, respectivamente. O tempo médio letal diminuiu à medida que a concentração e o tempo de exposição aumentaram. Os estudos histopatológicos realizados nas brânquias de $\boldsymbol{T}$. guineensis indicaram lesões que aumentaram progressivamente com a concentração do fluido. A fase larval é a mais suscetível ao fluido de perfuração. Concluiu-se que é necessário cuidado no manuseio de fluidos de perfuração no Delta do Niger, uma vez que esta é uma área de reprodução e berçário para várias espécies de peixes.

Palavras-chave: toxicidade, histopatologia, Delta do Niger, fluido de perfuração, concentração média letal $\left(L C_{50}\right)$, tempo médio letal $\left(L T_{50}\right)$, teleósteo.

\section{INTRODUCTION}

Natural resources such as oil and gas in the subterranean formation can be recovered by drilling wells that penetrate the formation. The well bore is drilled down to the formation using drilling fluid. During drilling process, the drilling fluid carries the drill cuttings in a return flow back to the platform. The drilling fluids and cuttings are usually discharged into the waters in the immediate vicinity of the drilling platform (OGP, 2004). Concern has grown in recent years because this practice may be damaging to the sensitive or highly productive ecosystem such as Niger delta wetland where most drillings are taking place in Nigeria.

The exact chemical compositions of many drilling fluids are not known. Gas chromatographic analysis has revealed that drilling fluids contain additives which are complex mixture of highly volatile materials and toxic substances such as heavy metals, hydrocarbon and organic compounds. These

IDepartment of Animal and Environmental Biology, Faculty of Science, University of Port Harcourt, Nigeria. E-mail: ijvincentakpu@yahoo.com.*Autor para correspondência.

IIDepartment of Fisheries, Livestock Production Technology, Niger Delta University Wilberforce Island, Nigeria. 
substances when discharged untreated into the environment are capable of interfering with normal functions of the organisms (PATIN, 1999; WILLS, 2000; SOEGIANTO et al., 2008). The drilling waste may kill marine life, smother or suffocate it with plume of suspended particles which results in potential damage to fish and invertebrate population and alteration in feeding and spawning grounds (CRAWFORD \& GATES, 1981; NEFF et al., 2000). According to PATIN (1999), ferrochrome lignosulfonate, a common drilling fluid additive used as a thinner and deflocculant, reduced survival and growth of fish egg and fry. The filtration control additive CMC (carboxy -metalcellulose) can cause death in fish fry at high concentrations (1000-2000 $\mathrm{mg} \mathrm{l}^{-1}$ ) and physiological changes such as lower feeding rates and higher mortality.

Median Lethal concentration $\left(96 \mathrm{~h} \mathrm{LC}_{50}\right)$ is a standard test used to determine the concentration of a chemical that will prove lethal to $50 \%$ of the test organisms in 96 hours. SAASEN et al. (2001) gave Median lethal concentrations $\left(\mathrm{LC}_{50}\right)$ of drilling fluids based on non-aromatic oil based muds (NAOBM) as (in $\mathrm{mg} \mathrm{l}^{-1}$ ): >100,000, 576, 76,088 and 1211 for marine algae - Skeletonema costatum; mussel - Abra alba; copepod - Acartia tonsa and amphipod - Corophium volutator respectively. NEFF et al. (1981) exposed 11 marine invertebrates to different drilling fluids and observed that the drilling fluids were acutely toxic to these organisms and the level of toxicity depended on the additives used.

Limanda limanda, a benthic flat fish exposed to treated and untreated drill cuttings tends to accumulate base oil and aromatic substances derived from the oil (STAGG \& MCINTOSH, 1996). For most aquatic organisms, the gills are major sites through which waterborne pollutants can enter the body, and gills are often affected by such substances including drilling fluid(SPRAGUE \& LOGAN, 1979; CRAWFORD \& GATES, 1981). In this study, the toxicity of a common drilling fluid (XP-07) was carried out on different life stages of a bony fish in the Niger delta to ascertain at what stage the organism is most susceptible to the drilling fluids and to observe any significant histological changes in the gill structures.

\section{MATERIALS AND METHODS}

\section{Test organisms}

The T. guineensis were collected from the African Regional Aquaculture Centre (ARAC), Buguma, Rivers State, Nigeria. In the laboratory, the fish were sorted out to different sizes depending on the life stages: fry (Fr) (0.52-0.55g), fingerlings (F) (5.51$5.56 \mathrm{~g})$ and post fingerlings (FP) (>10.5g) and transferred immediately to the holding tanks (ODIETE 2003). Fish were fed twice daily with NIOMR feed (35\% protein). Mortality during the holding period was less than one percent of the whole population.

Preparation of test materials

The test material is a synthetic based drilling fluid obtained from Bariod Nigeria Limited. The drilling fluid was stored in a 5 litre uncontaminated polyethelene containers at temperature of below $4^{0} \mathrm{C}$. Before the fluid was used, it was mixed in a storage bucket with a mixer at 3450rpm for $1 / 2$ hour.

Concentrations used for all the life stages, were $10 \%, 8 \%, 4 \%, 2 \%$ and $0 \% \operatorname{vol} / \operatorname{vol}\left(1 \%=1000 \mathrm{mg} \mathrm{l}^{-1}\right)$. Drilling fluid was added to the water and thoroughly mixed for 20 minutes and allowed to settle for 1 hour before the fish were introduced into the test chambers (REISH \& OSHIDA, 1986). The drilling fluid settled into a thin layer covering the bottom of the test chambers.

\section{Toxicity test}

A complete randomized design was carried out. Five treatments with 3 replicates were used for fry and fingerlings. Fifteen (25 litres) containers were used for the fry while fifteen (50 litres) containers were used for the fingerlings. For the post fingerlings, there were 5 treatments with 2 replicates and ten concrete ponds $(120 \mathrm{~cm} \backslash 120 \mathrm{~cm} \backslash 120 \mathrm{~cm})$ of 500 litres capacity were used. Ten fish were carefully placed into each replicate tank containing test solutions for diferent test concentrations.

The tests were conducted in the laboratory under room temperature using static non-renewal bioassay. The fish were kept with a $12 \mathrm{~h}$ light and $12 \mathrm{~h}$ dark light cycles and not fed during the bioassay. Water quality parameters of the test tanks were monitored daily for the replicates using standard methods (APHA, 1998).

Regular observations were made during the first $12 \mathrm{~h}$ and 24 hourly for 96 hours and mortality was used as a measure of toxicity. Fish which lost their equilibrium, floated ventral side up and did not respond to touch, were considered dead and removed immediately. The susceptibility of fish to drilling fluid was measured in terms of $96 \mathrm{~h}$ median lethal concentrations $\left(\mathrm{LC}_{50}\right)$. $\mathrm{LC}_{50}$, median lethal time $\left(\mathrm{LT}_{50}\right)$ and $95 \%$ confidence intervals were calculated with a computer program based on the probit analysis. 
Procedures for the Histopathology.

At 96h, two fish were sacrificed by a sharp blow to the head. The gills were cut, removed from the individual fish and processed using methods given by GOLDERASSOCIATES(1997).

\section{RESULTS}

The level of physicochemical parameters determined during the experiment at the various concentrations did not vary significantly $(\mathrm{P}<0.05)$ from those of the control. The mean temperature and dissolved oxygen values were $27.4 \pm 0.9^{0} \mathrm{C} ; 4.25 \pm 0.34 \mathrm{mg}$ $\mathrm{l}^{-1}$ respectively, while the alkalinity value was 22.28 $\pm 0.4 \mathrm{mg} \mathrm{l}^{-1}$ and $\mathrm{pH} 7.02 \pm 0.05$.

Within an hour of introduction of the fish, they were restless and made attempts to jump out of the tanks. These reactions to the toxicant were most pronounced in tanks containing the highest concentrations (10\%). However, these reactions subsided and the fish became calm as the experiment progressed.
Mortality of T. guineensis increased gradually up to $96 \mathrm{~h}$ with increasing drilling fluid concentrations, with 40-80\% mortality for the fry, 33$63 \%$ mortality for the fingerlings, and $40-73 \%$ mortality for the post fingerlings kept at 2, 4, 8 and 10\% XP-07 (Figure 1).

The 96h $\mathrm{LC}_{50}$ for XP-07 were 5.03, 7.77 and $6.93 \%$ for fry, fingerlings and post fingerlings respectively with the confidence intervals presented in table 1. The $\mathrm{LT}_{50}$ ranged from 48.81-95.58h for fry; 73.37-109.13h for fingerling and 57.89-106.74h for post fingerling exposed to the different concentrations (Table $2)$. Highest mortality was recorded in the fry stage.

In the histological study, gills of untreated T. guineensis revealed normal parallel arranged gill filaments, which consisted of primary lamellae and its delicate secondary lamellae arrays with all epithelial cells intact. However, changes in the gill filaments were observed after exposure to XP-07. In the fry exposed to $2 \%$ and $4 \%$ XP-07, there were epithelial lifting of the primary lamellae while in $8 \% \mathrm{XP}-07$, shortening and fusion of the secondary lamellae were observed. In

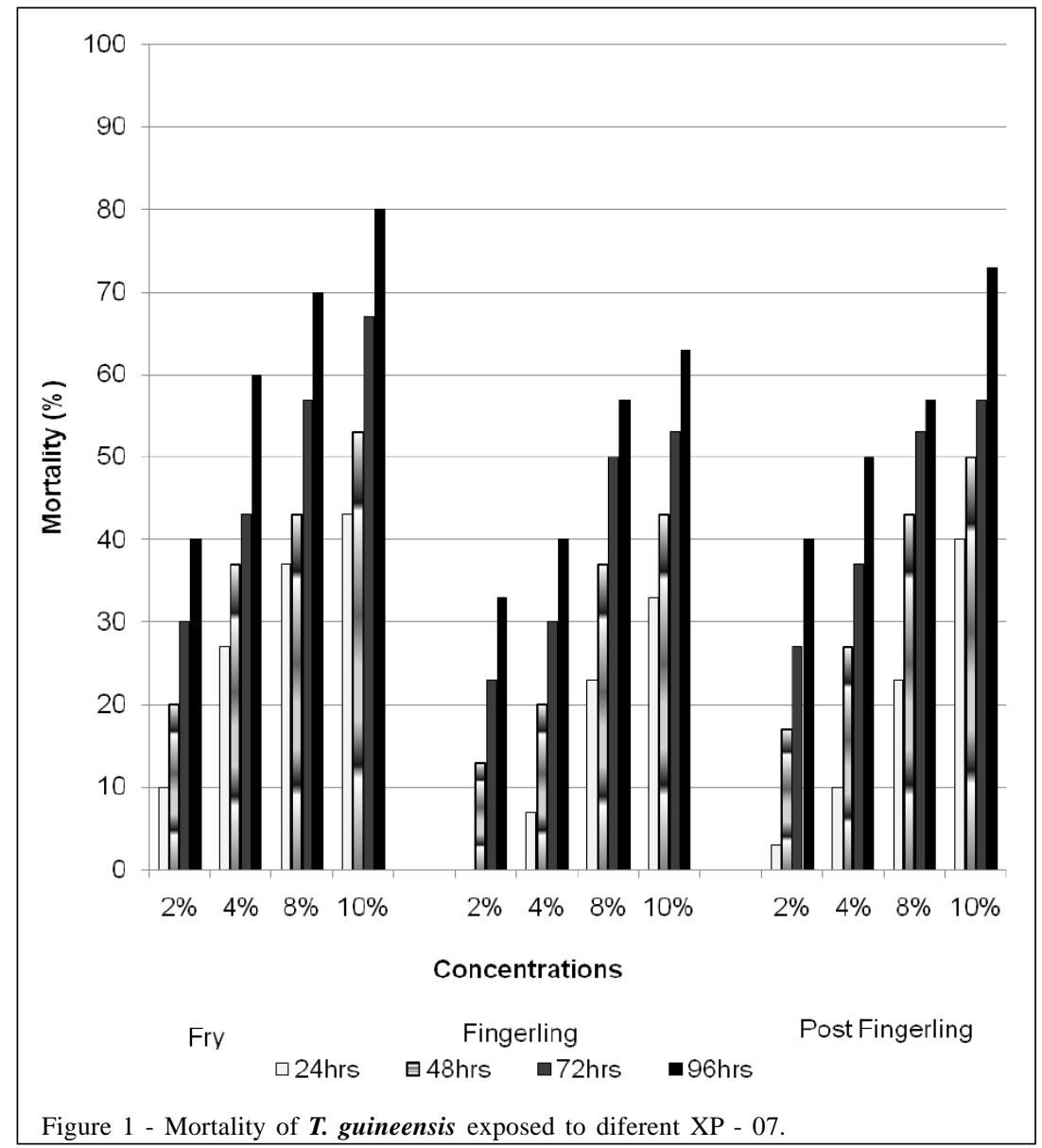

Ciência Rural, v.40, n.3, mar, 2010. 
Table 1 - Median lethal concentrations $\left(\mathrm{LC}_{50}\right)$ and 95\% confidence intervals of XP-07 on the different life stages of $\boldsymbol{T}$. guineensis in 96h.

\begin{tabular}{|c|c|c|c|c|}
\hline \multirow{2}{*}{ Life stages } & & & & \\
\hline & 24 & 48 & 72 & 96 \\
\hline $\mathrm{Fr}$ & $11.25 *(9.13-15.38)$ & $9.25 *(6.77-13.98)$ & $6.37 *(4.87-37.92)$ & $5.03 *(0.56-65.22)$ \\
\hline $\mathrm{F}$ & $11.52 *(0-15.38)$ & $10.42 *(8.55-14.37)$ & $8.44 *(5.27-32.62)$ & $7.77 *(29.03-64.86)$ \\
\hline $\mathrm{PF}$ & $11.30 *(9.85-15.07)$ & $9.22 *(7.58-12.16)$ & $8.56 *(3.34-178.76)$ & $6.93 *(3.94-194.76)$ \\
\hline
\end{tabular}

Note: *=confidence intervals; Fr=Fry; F=Fingerlings; PF=Post Fingerlings.

10\% XP-07, the fish samples had increased proliferation of epithelial cells and the proliferation was extensive that adjoning lamellae became fused (hyperplasia). Similar histological changes were observed in gill structures of the fingerlings and post fingerlings. The gills of fingerlings exposed to 2\% XP-07 had epithelial lifting on primary lamellae while epithelial lifting on primary and secondary lamellae occured in gills exposed to $4 \%$ and $8 \%$ XP-07. Fusion of adjacent lamellae was observed in 10\% XP-07. Lifting of the epithelia on the primary lamellae was detected in post fingerlings gills exposed to 2 and $4 \%$ XP-07, while disruption of the arrangement of the gill filament was noted in 8\% XP07. At the highest concentration(10\%), the epithelial cells lining lamellae undergo hyperplasia.

\section{DISCUSSION}

The percentage mortality, which increased progressively with increase in concentration of drilling fluid over time of exposure, is in agreement with previous findings using mollusc and annelids (BOWMER et al., 1996). The results of investigation on fish mortality indicated that XP-07 is acutely toxic to the different life stages of $\boldsymbol{T}$. guineensis. However, the acute toxicity was relatively low. The 96h $\mathrm{LC}_{50}$ values for the static bioassay with XP-07 for the three life stages varied from 5.03 to $7.77 \%$. This is probably because the fluid was not renewed daily during the 96h bioassay period. NEFF et al. (1981) noted that if aqueous mud fraction was renewed daily, its toxicity will increase several-fold, demonstrating that toxic components may be lost from solution by volatilization.

The toxicity of drilling fluids has been attributed to their hydrocarbon content (PARRISH \& WARD, 1988; NEFF et al., 2000). Low hydrocarbon content in XP-07 drilling fluid can be responsible for the low toxicity and also a synthetic based fluid, which does not readily disperse in water (WILLS, 2000). The fry was most sensitive to the drilling fluid which was in conformity with data from other workers (CARR et al., 1980; PARRISH \& WARD, 1988). However, NEFF et al. (1981) observed that juveniles of $N$. arenacedentata were slightly less sensitive when compared to the adult, because of the inactive feeding of the juvenile.

Based on the conventional toxicity rating classification system as a method of ranking relative toxicities of drilling fluids, XP-07 may be considered as being slightly toxic. The $96 \mathrm{LC}_{50}$ of XP-07 on $\boldsymbol{T}$. guineensis were within the range for slightly toxic category (SWAN et al., 1994).

Exposure of fish to XP-07 resulted in changes in the gills that were dose dependent, similar to what was obtained by SOEGIANTO et al. (2008) when Penaeus monodon was exposed to drilling waste. In addition, CERQUEIRA \& FERNANDES (2002) reported similar result in the freshwater fish Prochilodus scrofa exposed to copper. Abrasion or

Table 2 - Median Lethal Time ( $\left.\mathrm{LT}_{50}\right)$ and 95\% confidence intervals of XP-07 on the different life stages of $\boldsymbol{T}$. Guineensis.

\begin{tabular}{|c|c|c|c|c|}
\hline \multirow{2}{*}{ Life stages } & \multicolumn{4}{|c|}{ 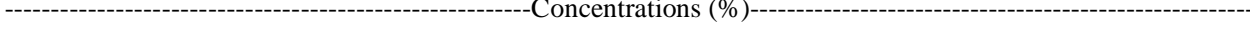 } \\
\hline & 2 & 4 & 8 & 10 \\
\hline $\mathrm{Fr}$ & $95.58 *(80.13-27.17)$ & $81.93 *(68.49-105.33)$ & $66.36 *(36.37-152.36)$ & $48.81 *(0-99.96)$ \\
\hline $\mathrm{F}$ & $109.13 *(92.70-149.0)$ & $102.83 *(86.19-139.61)$ & $76.29 *(63.91-95.75)$ & $73.37 *(0-11.62)$ \\
\hline $\mathrm{PF}$ & $106.74 *(89.80-145.9)$ & $92.68 *(78.38-120.23)$ & $67.70 *(57.15-81.52)$ & $57.89 *(0-60.91)$ \\
\hline
\end{tabular}

Note: *=Confidence intervals; Fr=Fry; F=Fingerlings; PF=Post Fingerlings.

Ciência Rural, v.40, n.3, mar, 2010. 
clogging of respiration surfaces occurred in rainbow trout when exposed to bentonite, a common drilling fluid additive (SPRAGUE \& LOGAN, 1979). The authors explained that these responses in rainbow trout were due to physical interactions with the respiratory surfaces, as opposed to chemical toxicity. Alterations that occurred in the gills as a result of exposure to XP07 include epithelial lifting, hyperplasia, lamella disruption or fusion, symptoms consistent with gill irritants. The morphological changes induced by drilling fluid in fish gill tissues have shown two types of responses: defense and compensatory responses. These responses help to reduce entry of toxicants, prevent them from reaching the blood stream and to a lesser extent, minimize damage caused by direct effect of toxicant (CERQUEIRA \& FERNANDES, 2002). The damage after exposure would lead to reduction in effective surface area, and an increase in diffusion distance for respiratory exchange.

The fry was most susceptible to the drilling fluid. Therefore, there is need to consider drilling fluids as pollutants of great significance, since the delta serves as a breeding ground for most fishes with their juveniles abounding there.

\section{REFERENCES}

APHA. Standard methods for the examination of water and wastewater. 20.ed. Washington DC.: APHA-AWWAWPCF, 1998. 1220p.

BOWMER, C.T. et al. An environmental evaluation of cleaned drill cuttings using a long-term model ecosystem bioassay. In:

The physical and biological effects of processed oily drill cuttings. London: E \& P Forum Joint Study, 1996. p.64-78. (Paper 6, n.2.61\202). Available from:<http:// www.anp.gov.br/brnd/round9/round9/guias_R9/perfuracao_R9/ Bibliografia/OILY_DRILL_CUT.PDF>. Accessed: nov. 28, 2009.

CARR R.S. et al. Influence of used chrome lignosulfonate drilling mud on the survival, respiration, feeding activity and net growth efficiency of the opossum shrimp Mysidopsis almyra. In: SYMPOSIUM: RESEARCH ON ENVIRONMENT FATE AND EFFECTS OF DRILLING FLUIDS AND CUTTINGS, 1980. Proceedings... Lake Buena Vista: American Petroleum Institute, Washington, DC. 1980. V.2, cChap.11, p.944-960.

CERQUEIRA, C.C.; FERNANDES M.N. Gill tissue recovery after copper exposure and blood parameter response in the tropical fish Prochilodus scrofa. Ecotoxicology and Environmental Safety, v.52, p.83-91, 2002. Available from: $<\mathrm{ht} \mathrm{t} \mathrm{p} \mathrm{:} \mathrm{/} \mathrm{/} \mathrm{w} \mathrm{w} \mathrm{w.} \mathrm{s} \mathrm{c} \mathrm{i} \mathrm{e} \mathrm{n} \mathrm{c} \mathrm{ed} \mathrm{i} \mathrm{r} \mathrm{e} \mathrm{c} \mathrm{t.} \mathrm{c} \mathrm{o} \mathrm{m} \mathrm{/}$ science?_ob=ArticleURL\&_udi=B6WDM-46C0D3S$1 \&$ \& us er $=10 \&$ \& coverDate $=06 \% 2$ F $30 \% 2$ F $2002 \&$ _rdoc $=1 \&$ \& fmt $=$ high \&_orig=browse\&_sort $=$ d\&view $=$ c \& _a c ct $=$ C $000050221 \&$ _version $=1 \&$ _ urlversion $=$ 0\& userid $=10 \&$ md5 $=$ d934253d0bbe05cef5956951be5b93b7 $>$. Accessed nov. 28, 2009. doi: 10.1006/eesa.2002.2164.
CRAWFORD,R.B.; GATES, J.D. Effects of a drilling fluid on the development of a teleost and an echinoderm. Bulletin of Environmental Contamination and Toxicology, v.26, p.207-212, 1981. Available from: <http://www.labmeeting.com/ paper/16289074/crawford-gates-1981-effects-of-a-drillingfluid-on-the-development-of-a-teleost-and-an-echinoderm>. Accessed: nov. 28, 2009. doi: 10.1074/jbc.M202849200.

GOLDER ASSOCIATES. Golder technical procedures. Fish health assessment - methods. Ontario, 1997. 28p. (Golder Technical paper). Available from: <http://www.ene.gov.on.ca/ envision/techdocs/4022App_IV.pdf>. Accessed: nov. 28, 2009.

NEFF, J.M. et al. Environmental impacts of synthetic based drilling. New Orleans, LA: U.S. Dept of the Interior Minerals Management Service. Gulf of Mexico, OCS Region, 2000. 154p. (Report prepared for MMS by Robert Ayers \&Associates, Inc. August 2000. Study MMS 2000-064). Available from: <http://www.gomr.mms.gov/pi/pdfimages/espis/ 3/3175.pdf $>$. Accessed: nov. 28, 2009.

NEFF, J.M. et al. Acute toxicity of a used chrome lignosulphonate drilling mud to several species of marine invertebrate. Marine Environmental Resource, v.4, p.251266, 1981. Available from: <http://www.sciencedirect.com/ s c i ence? o b = A r t i c le UR L \&_u d i $=$ B 6 V 7 H 4888FJKC\&_user $=10 \&$ \&coverDate $=04 \% 2 F 30 \% 2 F 1981 \&$ _alid $=11$ 02969316\&_rdoc $=31 \&$ \&mt $=$ high\&_orig $=$ search\&_cdi $=5843$ \&_docanchor $=\&$ view $=$ c\&_ct $=340 \& \_$acct $=$C000050221\& version $=1 \&$ url Versio $n=0 \&$ u s e ri d $=$ 10\&md5=b96e2f8f0f8e5aef58c1d31b121cf5c4>. Accessed: nov. 28, 2009. doi: 10.1016/0141-1136(81)90040-4

ODIETE, W.O. Standardization of test animals for toxicity evaluation for Environmental regulation in Nigeria. Journal of Nigeria Environmental Society (JNES) v.1, n.3, p.340350, 2003

OGP (OIL \& GAS PRODUCER). Environmental performance in the $\mathbf{E} \& \mathbf{P}$ industry - 2003. London, 2004. 31p. Available from: <http://www.org.uk/pubs/359.pdf >. Accessed: nov. 28, 2009.

PARRISH, P.R.; WARD, T.W. Variability of the toxicity of drilling fluids to mysids (Mysidopsis bahia). In: LICHTENBERG, J.J. et al. (Eds). Chemical and biological characterization of sludges, sediments, dredge spoils and drilling muds. Philadelphia, 1988. p.326-333. (ASTM STP 976).

PATIN, S.A. Environmental impact of the offshore oil and gas industry. East Northport, New York: Ecomonitor, 1999. 235p. Available from: <http://www.offshoreenvironment.com/wasteenvimpact.html>. Accessed: nov. 28, 2009.

REISH, D.J.; OSHIDA, P.S. Manual of methods in aquatic environmental research. Part 10. Short-term static bioassays. FAO, 1986. 62p. (FAO fish Technical Paper n.247). Available from: <http://www.archive.org/stream/manualofmethodsi034741mbp/ manualofmethodsi034741mbp_djvu.txt>. Accessed: nov. 28, 2009.

SAASEN, A. et al. The effect of drilling fluid base-oil properties on occupational hygiene and the marine environment. SPE Drilling and completion, v.16, n.3 p.150-153, 2001. 
Available from: <http://www.onepetro.org/mslib/servlet/ onepetropreview ?id=00073193\&soc $=\mathrm{SPE}>$. Accessed: nov. 28, 2009. doi: 10.2118/73193-PA.

SOEGIANTO, A. et al. Toxicity of drilling waste and its impact on gill structure of post larvae of tiger prawn (Penaeus monodon). Global Journal of Environmental Resource, v.2, n.1, p.36-41, 2008. Available from: <http://www.idosi.org/ gjer/gjer2(1)08/6.pdf>. Accessed: nov. 28, 2009.

SPRAGUE, J.B.; LOGAN, W.J. Separate and joint toxicity to rainbow trout of substances used in drilling fluids for oil exploration. Environmental Pollution v.19, n.4, p.269281, 1979. Available from: <http://www.sciencedirect.com/ sc i ence? _ o b = A r t i c le UR L \&_u di = B 75 C G 48 XD90M93\&_user $=10 \&$ \&doc $=1 \&$ \& fmt $=\&$ \&orig $=$ se arch\&_sort $=$ d\&_docanchor $=\&$ view $=$ c \&_searchStrId $=112$ $0327630 \&$ \&erunOrigin=google \&_acct $=$ C 00005022

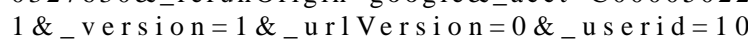
\&md5=d966926f02417785bac32ca6bb0cf073>. Accessed: nov. 28, 2009. doi: 10.1016/0013-9327(79)90119-8.
STAGG, R.M.; MCINTOSH, A. The effects of drill cuttings on Dab(Limanda limanda) In: The physical and biological effects of processed oily drill cuttings. London: E \& $\mathrm{P}$ Forum Joint Study, 1996. p.79-103. (Paper 7, n.2.61/202). Available from: <http://www.anp. gov.br/brnd/round9/round9/ g u i a s_R 9 / p e r f u r a c a o_R 9 / B i b li o g r a f i a / OILY_DRILL_CUT.PDF>. Accessed: nov. 28, 2009.

SWAN, J.M. et al. (Eds). Environmental implications of offshore oil and gas development in Australia -the findings of an independent scientific review. Sidney: Australian Petroleum Exploration Association, 1994. 157p.

WILLS, J. Muddied waters. A survey of oil field drilling wastes and disposal techniques to reduce the ecological impact of sea dumping. Sakhalin Environmental Watch, 2000. 139p. Available from: <http://www.offshoreenvironment.com/wasteenvimpact.html>. Accessed: nov. 28, 2009. 